\title{
Multilingual humour in a polyglot multicultural author: the case of Fouad Laroui
}

\author{
Cristina Vezzaro \\ Ghent University, Belgium \\ cristina.vezzaro@ugent.be
}

\section{Katrien Lievois}

University of Antwerp, Belgium

katrien.lievois@uantwerpen

\begin{abstract}
This paper focuses primarily on the Dutch and Italian translations of Fouad Laroui's works, in which the two central features of his writing, i.e. humour and multilingualism, are strictly related. Laroui is a transcultural author fluent in French, English, Dutch, dialectal Arabic and classical Arabic, and his works reflect the different layers of experiences and languages he has gathered during his life. Humour, on the other hand, is a way for him to present, in an axiological opposition, different viewpoints that mostly cross cultures, nationalities and social hierarchies. Our analysis of Le Jour où Malika ne s'est pas mariée and Une année chez les Français has allowed us to pinpoint the interaction between the two main features of his writing and examine the creation of puns by means of different languages or loanwords. We have then analysed the various strategies adopted by translators and commented their different solutions. Our analysis has allowed us to identify three different ways in which a third language (L3) in the source text - often connected to humour - is rendered in the target text, i.e. (1) taken as it is, (2) distorted or adapted to the target language and (3) kept with an intertextual or paratextual element or replaced altogether.
\end{abstract}

Keywords: Fouad Laroui, multilingualism, irony, humour, translation, transculturality, Italian, Dutch.

\section{Introduction}

Fouad Laroui is one of the leading contemporary writers of Moroccan origins, a multicultural polyglot author whose literary work is translated in French, Dutch, German, and English. Through the characters of his fictional works, Laroui retraces his own life experiences with the necessary distance and irony, on the fine line between the cultural and linguistic memory of his origins and his becoming. By his own admission, he only has "second languages" (Rey 
Mimoso-Ruiz \& Redouane, 2018). His multiculturalism and multilingualism place him both inside and outside cultures and languages, allowing him to have a privileged view on the worlds he crosses. Being an outsider often comes with a painful acknowledgement of exclusion, which he masterfully depicts through a reconciling irony whose aim it is to heal the wounds through an indulgent smile (Denooz 2011, our translation).

Irony and heterolingualism seem to be strictly related in Laroui's work. The author develops this connection in his remarks about multiculturalism by means of satirical passages, psychological considerations and intertextual wordplays (Lievois 2008; 2017).

Since quite a few of his novels are available in translation (Laroui 2003; 2005; 2009; 2010a; 2010b; 2012a; 2013; 2015b), Laroui's work offers an excellent opportunity to explore identity and social issues in multilingual humour and translation. We will start from his published translations to study the language and culture-bound challenges (Vezzaro 2016) found in translating multilingual humour.

\section{Fouad Laroui}

Born in Morocco, Fouad Laroui holds a degree in Engineering from the École nationale des ponts et chaussées in France and a $\mathrm{PhD}$ in Economics. He is a professor of French literature and Arabic culture at the University of Amsterdam, Netherlands, where he also lives. His work consists in a dozen novels and six collections of short stories in French, mostly published by Éditions Julliard. In 1996, when he first started to publish his novels in French, he had been living for quite a few years in the Netherlands and had already become a Dutch citizen.

In 2001, Laroui started to publish directly in Dutch. His first publication was Vreemdeling: aangenaam [= Nice to meet you, stranger] (2001b), printed by Van Oorschot, a press with an excellent reputation that had already chosen to publish the Dutch translations of his French novels. The book was followed by two collections of poems: Verbannen woorden [=Words in exile] in 2002 and Hollandse Woorden [Dutch words] in 2004.

Along with these Dutch works, he has constantly published essays, novels and collections of short stories in French. Between 1996 and 2017, Laroui has published about 25 texts in French altogether.

Only three years passed between the publication of Laroui's first novel and the date of the first printed translation. The Dutch version of his third book, Méfiez-vous des parachutistes, saw the light in 1999, the same year in which its French original was published. Many works have since been submitted to the Dutch public, starting with the translations of his novels up to 1999 and followed by five more novels published between 2003 and 2010 . Since then, Laroui has not been published in Dutch.

Surprisingly, it was precisely in 2010 that other linguistic and cultural areas started showing interest in the author of Moroccan origins. The first Italian translation of Le Jour où Malika ne s'est pas mariée was published in 2013, followed shortly afterwards by the 2015 translation of Une année chez les Français. That same year, the German public was able to read La vieille dame du Riad. The German translations of Les tribulations $d u$ dernier Sijilmassi and Ce vain combat que tu livres au monde were published in 2016 and 2017, while the English version of L'étrange affaire du pantalon de Dassoukine was issued in 2016.

We can therefore distinguish two different periods, at least in Europe: during the first one, Laroui's works are translated into Dutch, in an exclusive yet almost systematic way (nine publications); during the second period, his works are not translated into Dutch anymore, but they become available in German (3), Italian (2) and, to a lesser extent, in English (1). 
A third novel (Les tribulations du dernier Sijilmassi) should be published in 2019 in Italy, where Laroui has been widely appreciated. His L'esteta radicale (the Italian translation of Le Jour où Malika ne s'est pas mariée) was the recipient of the 2013 Premio Alziator. His literary interest in Italy is increased by a shared presence, though for different historic reasons, of large North African communities both in France and Italy. More recent waves of immigration in other European countries such as Germany may have had a similar effect, although he is also gaining momentum in English speaking countries.

In 2002, his collection of poems written in Dutch, Verbannen woorden, was shortlisted for the C. Buddingh' Prize, which is awarded every year in the Netherlands to the best first work in poetry. That same year he was honoured for his complete works with the E. du Perron Prize, awarded to those who have made an important contribution to good relations between the various communities in the Netherlands. Frans Van Woerden, thus far his Dutch translator, enjoys a solid reputation in his field, mainly thanks to his translations of LouisFerdinand Céline's works that have won him the 1988 Martinus Nijhoff Prize, awarded every year to the best translation from or into Dutch.

This paper will focus primarily on Une année chez les Français and Le jour où Malika ne s'est pas mariée, the two texts that have been translated both into Dutch and Italian, as well as on La femme la plus riche du Yorkshire and La fin tragique de Philomène Tralala, both translated into Dutch.

\section{Multilingualism and humour}

Born into a situation of diglossia as described by Charles Ferguson (1959), in several of Fouad Laroui's novels multilingualism is obviously part of the mimesis, thus reflecting the linguistic situation of the context in which the novels are rooted. Arabic is therefore very present in Une année chez les Français, set in Casablanca, whereas English is far more frequent in La femme la plus riche du Yorkshire.

The translator will necessarily have to consider this incidence of multilingualism, though $\mathrm{s} /$ he may not always have to render it in the same way. The presence of foreign languages in Laroui's novels is evidently due to his personal transculturality. Laroui is fluent in French, English, Dutch, dialectal Arabic and classical Arabic, and these languages are often present in his texts. English is used in the novel set in England, whereas Moroccan characters sometimes speak Arabic. The author also uses Latin, albeit usually in the most common expressions that are now part of French. Laroui is aware that English and Latin may well be understood by his readership, and therefore rarely translates or explains these parts; on the other hand, he often introduces, translates or explains the parts in Arabic, which very few French readers will be able to understand. Therefore, his translators usually can follow the author's lead and offer a similar experience to the readers in their languages. Here are some examples (1 and 2 ) of words or sentences in a foreign language that do not require any particular intervention in translation:

\section{Example 1}

\begin{tabular}{|l|l|l|}
\hline ST & Backtranslation & TT \\
\hline $\begin{array}{l}\text { As-sâlâmu 'alaykum ! La } \\
\text { paix soit sur toi, si el haj. } \\
\begin{array}{l}\text { Tout va bien? La santé, la } \\
\text { famille? Hamdullah! }\end{array}\end{array}$ & $\begin{array}{l}\text { - As-sâlâmu 'alaykum! } \\
\text { upon you, si el haj. Is } \\
\text { everything alright? } \\
\text { Your health, your }\end{array}$ & $\begin{array}{l}\text { Dutch: As-sâlâmu 'alaykum! Vrede zij } \\
\text { met u, si el haj. Gaat het goed met u? } \\
\text { De gezondheid, de familie? } \\
\text { Hamdoullah! (Laroui 2012a: 231) }\end{array}$ \\
\hline
\end{tabular}




\begin{tabular}{|l|l|l|}
\hline (Laroui 2010b: 231) & family? Hamdullah! & $\begin{array}{l}\text { Italian: }- \text { As-sâlamu 'alaykum! La } \\
\text { pace scenda su di te, si el haj. Va tutto } \\
\text { bene? La salute, la famiglia? } \\
\text { Hamdullah! (Laroui 2015b: 268) }\end{array}$ \\
\hline
\end{tabular}

While the foreign words in Arabic are explained in in the source text (example 1), English is usually considered a common language that does not need any translation:

\section{Example 2}

\begin{tabular}{|c|c|c|}
\hline ST & Backtranslation & TT \\
\hline $\begin{array}{l}\text { - Mais au fait, je ne connais } \\
\text { pas votre nom. Qu'à cela ne } \\
\text { tienne, il le lui révèle. - My } \\
\text { name is Adam Serghini! Elle } \\
\text { fronce les sourcils. - C'est } \\
\text { français, ça ? On dirait un } \\
\text { nom italien. - Not exactly, } \\
\text { lui dit-il, très fier. Adam, } \\
\text { c'est dans toutes les langues } \\
\text { du monde. Quant à Serghini } \\
\text { [...]. - Quelle drôle d'idée } \\
\text { de vos parents de s'appeler } \\
\text { ainsi. - I I faut les excuser : } \\
\text { ils sont ressortissants de } \\
\text { l'Empire chérifien. Et moi } \\
\text { aussi. - Hein ? Comment? } \\
\text { What? Vous n'êtes pas } \\
\text { français? -Ben non, I am } \\
\text { Moroccan. (Laroui 2008b: } \\
\text { 28-29) }\end{array}$ & $\begin{array}{l}\text { - Actually, I don't } \\
\text { know your name. If that } \\
\text { is all she wants, he } \\
\text { reveals it to her. -My } \\
\text { name is Adam Serghini! } \\
\text { She frowns. - Is this } \\
\text { French ? It sounds } \\
\text { Italian. - Not exactly, he } \\
\text { tells her proudly. Adam } \\
\text { is to be found in all the } \\
\text { languages of the world. } \\
\text { Concerning Serghini } \\
\text { [...]. - How did your } \\
\text { parents come up with } \\
\text { such a name? - They } \\
\text { are to be excused: they } \\
\text { are citizens of the } \\
\text { Cherifian Empire. And } \\
\text { so am I. - Why... Wait! } \\
\text { What? You are not } \\
\text { French? - Well, no, I } \\
\text { am Moroccan. }\end{array}$ & $\begin{array}{l}\text { Dutch: 'Ik weet eigenlijk helemaal niet } \\
\text { hoe u heet.' O, als dat alles is, nou dat } \\
\text { zal hij haar wel eventjes onthullen. 'My } \\
\text { name is Adam Serghini!' Ze fronst haar } \\
\text { wenkbrauwen. 'Is dat Frans? Het klinkt } \\
\text { meer Italiaans.' 'Not exactly', zegt hij } \\
\text { heel trots tegen haar. Adam, dat heb je } \\
\text { in alle talen van de wereld. Maar waar } \\
\text { Serghini vandaan komt, ja, [...] 'Wat } \\
\text { een raar idee van uw ouders om zich zo } \\
\text { te noemen.' 'Je moet het ze maar niet } \\
\text { kwalijk nemen: ze zijn inwoners van } \\
\text { sjerifische rijk. Net als ik.' 'Hè? Wat? } \\
\text { What? Bent u geen Fransman?' 'Nou, } \\
\text { nee, I am Moroccan.' }\end{array}$ \\
\hline
\end{tabular}

Latin, on the other hand, is perceived and used differently according to the target language:

\section{Example 3}

\begin{tabular}{|l|l|l|}
\hline ST & Backtranslation & TT \\
\hline $\begin{array}{l}\text { On revint au statu quo ante. } \\
\text { (Laroui 2009: 47) }\end{array}$ & $\begin{array}{l}\text { And we were back to } \\
\text { the start. }\end{array}$ & $\begin{array}{l}\text { Dutch: En toen was iedereen weer } \\
\text { terug bij 'af' (Laroui 2010a: 44) }\end{array}$ \\
& $\begin{array}{l}\text { Italian: Si tornò allo statu quo ante } \\
\text { (Laroui 2013: 35) }\end{array}$ \\
\hline
\end{tabular}

\section{Example 4}

\begin{tabular}{|l|l|l|}
\hline ST & Backtranslation & TT \\
\hline $\begin{array}{l}\text { L'autre, (...), se contentait } \\
\text { d'esquisser quelque }\end{array}$ & $\begin{array}{l}\text { The other one, (...), was } \\
\text { satisfied with a hint of a }\end{array}$ & $\begin{array}{l}\text { Dutch: De ander, (...), beperkte zich } \\
\text { wat ingehouden gegrom - slechts een }\end{array}$ \\
\hline
\end{tabular}




\begin{tabular}{|l|l|l|}
\hline $\begin{array}{l}\text { rugissement in petto }- \text { seule } \\
\text { l'oreille exercée pouvait } \\
\text { percevoir les vibrations } \text { in } \\
\text { potentia. (Laroui 2009: 186) }\end{array}$ & $\begin{array}{l}\text { roar in petto - only a } \\
\text { well-trained ear could } \\
\text { catch the vibrations in } \\
\text { potentia. }\end{array}$ & $\begin{array}{l}\text { geoefend oor kon de potentiële } \\
\text { vibraties (...) waarnemen. (Laroui } \\
\text { 2010a: 172) }\end{array}$ \\
& & $\begin{array}{l}\text { Italian: L'altro, (...), si accontentava di } \\
\text { accennare qualche ruggito in pectore, } \\
\text { solo un orecchio esercitato poteva }\end{array}$ \\
& & $\begin{array}{l}\text { percepire le vibrazioni in potentia. } \\
\text { (Laroui 2013: 135) }\end{array}$ \\
\hline
\end{tabular}

\section{Example 5}

\begin{tabular}{|l|l|l|}
\hline ST & Backtranslation & TT \\
\hline $\begin{array}{l}\text { Maintenant, c'était une } \\
\text { superbe paire de fesses qui } \\
\text { proclamait } \text { urbi et orbi les } \\
\text { mérites d'une marque de } \\
\begin{array}{l}\text { lingerie bien connue. } \\
\text { (Laroui 2009: 128) }\end{array}\end{array}$ & $\begin{array}{l}\text { A superb butt was now } \\
\text { proclaiming } \text { urbi et orbi } \\
\text { the merits of a popular }\end{array}$ & $\begin{array}{l}\text { Dutch: Nu hingen er een paar } \\
\text { schitterende billen die wijd en zijd de } \\
\text { kwaliteiten van een welbekend } \\
\text { lingeriemerk rondbazuinden. (Laroui }\end{array}$ \\
& & $\begin{array}{l}\text { 2010a: 120) } \\
\text { Italian: Ora c'era uno splendido paio di } \\
\text { glutei a proclamare } \text { urbi et orbi i meriti } \\
\text { di un noto marchio di biancheria } \\
\text { intima. (Laroui 2013: 94) }\end{array}$ \\
\hline
\end{tabular}

The Latin expressions "statu quo ante" (example 3), "in potentia" (example 4) and "urbi et orbi" (example 5) are kept in the Italian, where their use is probably just as common as in French, but not in Dutch. In example 5, the humour of the sentence is precisely due to the combination of the Latin expression, which is usually associated to the solemn benediction of the Pope in Rome, and a "butt." In the case of the Italian expression "in petto" (example 4), it would lose its effect in the Italian text, so it is itself translated into Latin and becomes "in pectore."

\section{Example 6}

\begin{tabular}{|l|l|l|}
\hline ST & Backtranslation & TT \\
\hline $\begin{array}{l}\text { La chaleur ambiante n'avait } \\
\text { pas dissous notre libido } \\
\text { sciendi. (Laroui 2009: 106) }\end{array}$ & $\begin{array}{l}\text { The ambient heat } \\
\text { around us had not } \\
\text { dissolved our libido } \\
\text { sciendi. }\end{array}$ & $\begin{array}{l}\text { Dutch: De hitte had onze libido sciendi } \\
\text { nog niet doen verdampen. (Laroui } \\
\text { 2010a: 99) } \\
\end{array}$ \\
& $\begin{array}{l}\text { Italian: Il calore ambiente non aveva } \\
\text { dissolto la nostra libido sciendi. (Laroui } \\
\text { 2013: 78) }\end{array}$ \\
\hline
\end{tabular}

This is a very good example of how Laroui plays with the language to produce a humoristic image: the adjective "ambient" does not necessarily add to the idea of heat. However, we have to consider the context. The characters in this short-story are sitting on a café terrace letting the very hot day go by, when a passer-by approaches them asking where the "Agence urbaine" is, i.e. the technical office for building permits. The author chooses the term "ambient heat" instead of simply adding any other adjective that could describe the great heat. Now, "ambient heat" is the scientific term for "thermal energy that is freely available from the surrounding environment." We have to remember that Laroui holds a degree in 
Engineering, so the author plays here with a specific terminology to achieve a humoristic effect. The same happens when he uses the Latin term "libido sciendi" - the desire of knowledge, usually applied to knowledge in a broader sense - to introduce the following sentence addressed to the passer-by (in our free translation): "What do you want from that office? Are you planning the construction of a building? Of some villas? A mall, maybe?" The characters' libido sciendi is here reduced to mere curiosity. In both cases there is a sliding of a very precise terminology towards a more general sense and a slightly different meaning. This is what creates the humor of this sentence. The Italian proximity to French allows the translator to keep the same linguistic choices.

We can therefore see how the reception of Latin expressions differs in the Dutch translation and in the Italian translation. While the Dutch translator seems to privilege Dutch expressions and drops the Latin in most of the examples, the Italian translator chooses to keep and even reinforce the estrangement effect generated by Latin expressions. This is probably due to a greater similarity between the use of Latin in French and Italian, where Latin expressions are more present in the common language and are also more easily understandable to readers not necessarily familiar with Latin. The effect of a natural multilingualism is thus kept in Italian, whereas it may actually become too forced or artificial in Dutch.

It is worth mentioning that literary polyglossia satisfies more than a mere realistic function and cannot be confused with social polyglossia. The coexistence of various languages and genres in a literary text must be analysed beyond their sheer linguistic meaning and considering their wider significance. In Laroui, it becomes a fundamental part of the humorous and ironic ethos that characterizes all his works.

From a stylistic standpoint, irony is attained through the use of very frequent tropes, among which there is repetition, hyperbole, exaggeration, etc. The ironic quality of Laroui's works is not simply due to the mere presence of multilingualism, but rather to its high frequency. Furthermore, multilingualism often coincides with multiculturalism, thus paving the way for yet another fundamental feature of irony, i.e. the axiological opposition. To present different cultures within one work also means to present different visions of the world which, thanks to irony, do not necessarily have to be antagonistic or incompatible. While it can certainly have a cutting edge, irony can also allow to depict different truths with a smiling and benevolent eye without having to reject one and keep the other (Hutcheon 1998; Schoentjes 2001).

This particular feature of irony is sometimes accomplished by the narrative device of the double look. Some of his characters are particularly fit for this purpose and easily allow an indirect glance on society (Hamon 1996: 177), as is the case for the child in Une année chez les Français and the foreigner representing himself as an amateur ethnologist in La femme la plus riche du Yorkshire. In Laroui's works, the device of the double look is emphasized by multilingualism: the use of a language indicates the culture to which the various characters belong.

\section{Example 7}

\begin{tabular}{|l|l|l|}
\hline ST & Backtranslation & TT \\
\hline Répétez, Petit-Breton! & Repeat, Little Breton! & $\begin{array}{l}\text { Dutch: Zeg me na, Petit-Breton! Dulce } \\
\text { et decorum... }\end{array}$ \\
- Dulce et decorum... & Dulce et decorum... & -Douché et décor homme... (Laroui \\
(Laroui 2010b: 64) & - Douche \& deck a & 2012a: 59-60) \\
& & Italian: Ripeta, Piccolo Bretone! Dulce \\
\hline
\end{tabular}




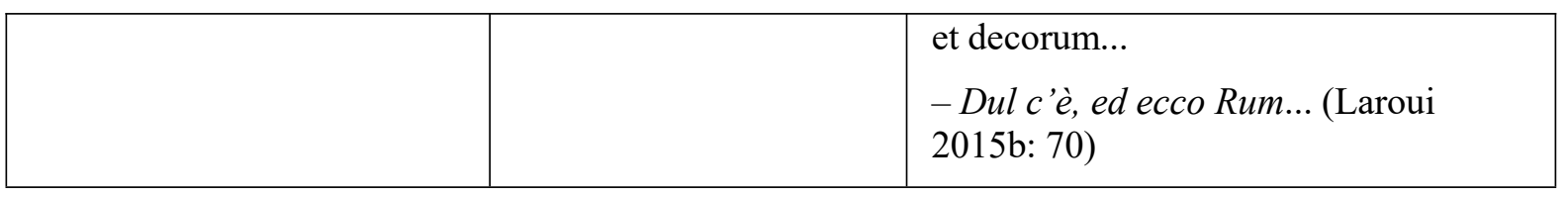

Here little Mehdi tries to interpret the adult's Latin with the words he knows, thus funnily readjusting the quotation to his own idiolect. The result is obviously absurd. The proximity of Italian to Latin makes it easier for the Italian translator to recreate the pun, whereas the Dutch translator chooses to keep it in French.

Among other humorous techniques that are widely adopted and that Laroui also regularly uses, we can find the switch to a different linguistic register (Chiaro 2017: 416; Delabastita \& Grutman 2005: 18 ; Lievois 2014 : 195). The characters thus portrayed in a mocking way belong to all nationalities and social origins: Francophones with an English accent (ex. 8 and 9), English people muttering French words (ex. 10), Moroccans mangling French and merrily mixing various linguistic registers and languages (ex. 11), etc. In all these cases, the words are often misspelled.

\section{Example 8}

\begin{tabular}{|l|l|l|}
\hline ST & Backtranslation & TT \\
\hline $\begin{array}{l}\text { Cheute ze faque eup! } \\
\text { (Laroui 2003: 46) }\end{array}$ & Shut the fuck up! & $\begin{array}{l}\text { Dutch: Sjut de fuk up! (Laroui 2005: } \\
\text { 42) }\end{array}$ \\
\hline
\end{tabular}

\section{Example 9}

\begin{tabular}{|c|c|c|}
\hline ST & Backtranslation & TT \\
\hline $\begin{array}{l}\text { Petit menteur! Tu prétends } \\
\text { lire La Fontaine comme ça? } \\
\text { Sans raison? For fun? For ze } \\
\text { hell of it? (Laroui 2010b: } \\
\text { 198) }\end{array}$ & $\begin{array}{l}\text { You little liar! You're } \\
\text { telling me that you are } \\
\text { reading La Fontaine for } \\
\text { the sake of it? Without } \\
\text { any reason? For fun? } \\
\text { For ze hell of it? }\end{array}$ & $\begin{array}{l}\text { Dutch: Kleine jokkebrok! Wou je soms } \\
\text { beweren dat je zomaar wat in La } \\
\text { Fontaine ligt te lezen? Zonder enige } \\
\text { reden? For fun? For ze hell of it? } \\
\text { (Laroui 2012a: 175) } \\
\text { Italian: Piccolo bugiardo! Vuoi dirmi } \\
\text { che leggi La Fontaine cosi? Senza } \\
\text { ragione? For fun? For ze hell of it? } \\
\text { (Laroui 2015b: 204) }\end{array}$ \\
\hline
\end{tabular}

It is interesting to see how both the Dutch and the Italian versions in examples 8 and 9 keep the French pronunciation Laroui is making fun of ("ze"), while both languages most certainly also have stereotyped mispronunciations of the English language. The same thing happens in the Dutch translation of "DiGowl" (example 10). This probably has to do with yet another cliché, i.e. the idea that French and English have a particularly hard time pronouncing foreign languages. 
Example 10

\begin{tabular}{|c|c|c|}
\hline ST & Backtranslation & TT \\
\hline $\begin{array}{l}\text { [Elle contemple] d'un air } \\
\text { dédaigneux la photo du } \\
\text { général de Gaulle. Elle } \\
\text { informe Adam du fait } \\
\text { indéniable que Churchill, } \\
\text { c'était mieux que DiGowl. } \\
\text { Et d'abord, il est né où, } \\
\text { DiGowl? (Laroui 2008b: 49) }\end{array}$ & $\begin{array}{l}\text { She scornfully observes } \\
\text { a picture of General De } \\
\text { Gaulle. She informs } \\
\text { Adam of an undeniable } \\
\text { truth, i.e. that Churchill } \\
\text { was better than DiGowl. } \\
\text { And apart from that, } \\
\text { where was he born, } \\
\text { DiGowl? }\end{array}$ & $\begin{array}{l}\text { Dutch: Terwijl ze een minachtende } \\
\text { blik werpt op de foto van generaal De } \\
\text { Gaulle. Ze stelt Adam op de hoogte van } \\
\text { het onomstotelijke feit dat Churchill } \\
\text { wel even van een andere orde was dan } \\
\text { DiGowl. Trouwens, waar was-ie } \\
\text { eigenlijk geboren, DiGowl? (Laroui } \\
\text { 2008a: } 47 \text { ) }\end{array}$ \\
\hline
\end{tabular}

\section{Example 11}

\begin{tabular}{|l|l|l|}
\hline ST & Backtranslation & TT \\
\hline $\begin{array}{l}\text { Miloud hésita un instant, } \\
\text { puis il rugit, à faire trembler } \\
\text { les murs : - Un pitchoun, } \\
\text { deux bibis et une falise! } \\
\text { (Laroui 2010b: 10) }\end{array}$ & $\begin{array}{l}\text { Miloud hesitated a } \\
\text { fraction, then barked so } \\
\text { loud, that the walls } \\
\text { trembled: - One } \\
\text { pitchoun, two turkeys } \\
\text { and one suitcase! }\end{array}$ & $\begin{array}{l}\text { Dutch: Miloud aarzelde even, toen } \\
\text { loeide hij zo hard dat de muren ervan } \\
\text { trilden : Eén pitchoun, twee bibi's en } \\
\text { één falies! (Laroui 2012a: 12) } \\
\text { Italian: Miloud esitò un attimo, quindi } \\
\text { sbraitò da far tremare i muri: - Un } \\
\text { pitchoun, due ticchini e una faligia! } \\
\text { (Laroui 2015b: 14) }\end{array}$ \\
\hline
\end{tabular}

In this example, three different words are problematic in translation: "pitchoun," "bibis" and "falise." Both translators keep "pitchoun,",which is explained in the glossary at the end of the Italian translation [Pitchoun: Piccolino (francese regionale, dall'occitano)]. In Italian, the word reminds of a word (piccino) and dialectal words with a similar sound (picciriddu, piccirillo) which will allow the reader to understand the meaning. The Dutch translator keeps "bibi's" but "Dutchifies" "falise" to "falies," keeping the "f" in place of the "v" that would be the correct spelling in both the source and the target language. The Italian translator translates them both, choosing the semantic significant over the formal sign, but keeping an estranging effect in the pronunciation.

Sometimes, readers in the original language and readers of the translation will have a different experience because of the crossing between cultural references. Here is an interesting example:

\section{Example 12}

\begin{tabular}{|c|c|c|}
\hline ST & Backtranslation & TT \\
\hline $\begin{array}{l}\text { John ne riait pas. «Vind je } \\
\text { dit grappig?» Il vit les mots } \\
\text { flotter devant ses yeux avec } \\
\text { la traduction française : «Et } \\
\text { vous trouvez ça drôle?» } \\
\text { qu'il connaissait parce } \\
\text { qu'un jour Annie lui avait } \\
\text { fait entendre un sketch de }\end{array}$ & 1 & $\begin{array}{l}\text { English: John didn't laugh. "Vind je dit } \\
\text { grappig?" He saw the words float } \\
\text { before his eyes with the French } \\
\text { translation: "Et vous trouvez ça drôle?" } \\
\text { which he knew because one day Annie } \\
\text { had made him listen to a sketch by } \\
\text { Coluche which has ended in those }\end{array}$ \\
\hline
\end{tabular}




\begin{tabular}{|l|l|l|}
\hline $\begin{array}{l}\text { Coluche qui se terminait par } \\
\text { ces mots. (Laroui 2012b: } \\
99)\end{array}$ & words. (Laroui 2016b: 76) \\
\hline
\end{tabular}

In this case, the English translator chooses to keep the Coluche quotation in French and does not translate the Dutch and French questions. While the phrasing allows to understand that the Dutch sentence is a translation of the French sentence, the English reader will not have a similar experience as the Dutch or French reader, since the sentence is ultimately not translated into her/his own language. Since the short story takes place in Bruxelles, though, the Verfremdungseffekt Laroui introduces is thus kept in English.

\section{Example 13}

\begin{tabular}{|c|c|c|}
\hline ST & Backtranslation & TT \\
\hline $\begin{array}{l}\text { Mais attends, protesta sa } \\
\text { poule, y a encore le } \\
\text { deuxième film. C'est un } \\
\text { western. Quinze potences } \\
\text { pour un salopard. Quinze! } \\
\text { J'adore les westerns, y a } \\
\text { plein de paysages. Et y a les } \\
\text { chevaux aussi. Et y a Jaune } \\
\text { Ouène dans le rôle du héros. } \\
\text { (Laroui 2010b: 139) }\end{array}$ & $\begin{array}{l}\text { But wait, protested his } \\
\text { chick, there's a second } \\
\text { movie. It's a western. } \\
15 \text { Scaffolds for a } \\
\text { Murderer. 15! I love } \\
\text { westerns, with all the } \\
\text { landscapes. And all the } \\
\text { horses. And John } \\
\text { Wayne playing the } \\
\text { hero. }\end{array}$ & $\begin{array}{l}\text { Dutch: Wacht nou es eventjes;' } \\
\text { protesteerde zijn mokkel, “er is toch } \\
\text { een tweede film. Da's een western. } \\
\text { Vijftien galgen voor een boef. Vijftien! } \\
\text { Ik ben dol op westerns, vanwege de } \\
\text { landschappen. En je hebt ook al die } \\
\text { paarden. En Sjoon Ween in de } \\
\text { heldenrol." (Laroui 2012a: 124) } \\
\text { Italian: - Ma aspetta, - protestò la sua } \\
\text { cocca, - c'è ancora l'altro film. È un } \\
\text { western. Quindici forche per un } \\
\text { assassino. Quindici! Adoro i western, } \\
\text { ci sono tanti paesaggi. E anche i } \\
\text { cavalli. E Jaune Ouène nella parte } \\
\text { dell'eroe. (Laroui 2015b: 145) }\end{array}$ \\
\hline
\end{tabular}

While the movie is originally Italian, and the Italian name is thus taken in Italian, the Dutch translator chooses to translate it, which is unusual in Dutch, where movies mostly keep their names since they are usually shown in the original language in the Netherlands and Belgium. Also, the distorted name of John Wayne is adapted in Dutch and not in Italian. While the Italian translation simply maintains the mispronunciation, the Dutch translator changes the Frenchification of John Wayne's last name into a Dutch similar sound ("Ween"), an existing word that means "to cry," thus recreating a Dutch equivalent for the humorous expedient.

On a different note, the ambiguity of translation helps characters show how different languages mean different cultures. An example of translation in the French original is a good way to prove this difference. In example 14, the aunt does not speak any French, and while Mehdi's answer to a very simple question "How are your teachers" is just a simple "Good," the cousin embarks on a very long and detailed - though fictional - translation or rather interpretation of a simple word.

\section{Example 14}

\begin{tabular}{|l|l|l|}
\hline ST & Backtranslation & TT \\
\hline $\begin{array}{l}\text { La tante. }- \text { Comment sont } \\
\text { tes professeurs, } a \text { wlidi? }\end{array}$ & $\begin{array}{l}\text { The aunt: }- \text { How are } \\
\text { your teachers, } a \text { wlidi } ?\end{array}$ & $\begin{array}{l}\text { Dutch: De tante }: \text { Hoe zijn je leraren, } a \\
\text { wlidi? Mehdi }: \text { Goed. Taheb }\end{array}$ \\
\hline
\end{tabular}




\begin{tabular}{|c|c|c|}
\hline $\begin{array}{l}\text { Mehdi: - Bien. Tayeb } \\
\text { (traduisant): - Il dit que ses } \\
\text { professeurs sont très } \\
\text { ma'qoul, très sérieux, mais } \\
\text { ce sont malheureusement } \\
\text { des incroyants, des kouffar, } \\
\text { jamais ils ne font la prière et } \\
\text { il paraît qu'il y en a qui } \\
\text { vivent avec des femmes } \\
\text { avec lesquelles ils ne sont } \\
\text { même pas mariés! Mais } \\
\text { c'est comme ça, ils sont } \\
\text { comme ça, les Français, } \\
\text { voilà, c'est ce qu'il a dit. } \\
\text { (Laroui 2010b: 266) }\end{array}$ & $\begin{array}{l}\text { Mehdi: - Good. Tayeb } \\
\text { (translating): - He says } \\
\text { his professors are very } \\
\text { macqoul, very serious, } \\
\text { but unfortunately they } \\
\text { are infidels, kouffar, } \\
\text { they never pray, and } \\
\text { apparently some of } \\
\text { them live with women } \\
\text { they are not even } \\
\text { married to! But that's } \\
\text { how it is, this is who } \\
\text { they are, the French, } \\
\text { this is what he said. }\end{array}$ & $\begin{array}{l}\text { (vertalend) : Hij zegt dat zijn leraren } \\
\text { heel ma'qoul, zijn, heel serieus, maar } \\
\text { ze zijn jammer genoeg ongelovig, het } \\
\text { zijn kouffar, ze bidden nooit en } \\
\text { sommige schijnen zelfs samen te leven } \\
\text { met vrouwen met wie ze niet getouwd } \\
\text { zijn! Maar zo is dat nu eenmaal, zo zijn } \\
\text { ze eenmaal, de Fransen, dat is wat hij } \\
\text { heeft gezegd. (Laroui 2012a: 234-235) } \\
\text { Italian: La zia: - Come sono i tuoi } \\
\text { professori, a wlidi? Mehdi: - Bravi. } \\
\text { Tayeb (traducendo): - Dice che i suoi } \\
\text { professori sono molto macqoul, molto } \\
\text { seri, ma purtroppo sono dei miscredenti, } \\
\text { dei kouffar, non fanno mai la preghiera, } \\
\text { e a quanto pare alcuni vivono con delle } \\
\text { donne con cui non sono nemmeno } \\
\text { sposati! Ma è così, sono fatti così, i } \\
\text { francesi, ecco cos'ha detto. (Laroui } \\
\text { 2015b: 272) }\end{array}$ \\
\hline
\end{tabular}

A similar excerpt exemplifying this method can be found in the same novel. When addressed in Arabic, little Mehdi does not fully understand the sentences. In an Arabic expression describing the kid's height and comparing it to a bean, the child does not get the figurative sense of the comparison:

\section{Example 15}

\begin{tabular}{|c|c|c|}
\hline ST & Backtranslation & TT \\
\hline $\begin{array}{l}\text { La sorcière le regarda avec } \\
\text { hostilité et dit, en arabe, en } \\
\text { faisant la moue : - Gueddou } \\
\text { gued el-foula! Mehdi ne } \\
\text { comprit pas tout mais ça } \\
\text { n'avait pas l'air très gentil. } \\
\text { El-foula, ça voulait dire la } \\
\text { fève. On le traitait de fève? } \\
\text { Voilà qui était nouveau. } \\
\text { (Laroui 2010b: 134) }\end{array}$ & $\begin{array}{l}\text { The witch looked at him } \\
\text { with hostility and said } \\
\text { in Arabic, making a wry } \\
\text { face: - Gueddou gued } \\
\text { el-foula! Mehdi did not } \\
\text { fully understand, but it } \\
\text { did not sound like a } \\
\text { nice exclamation. El- } \\
\text { foula meant fava bean. } \\
\text { Were they calling him a } \\
\text { fava bean? That was a } \\
\text { first. }\end{array}$ & $\begin{array}{l}\text { Dutch: De heks keek hem vijandig aan } \\
\text { en zei pruilend, in het Arabisch: } \\
\text { "Gueddou gued el-foula!.” Mehdi } \\
\text { begreep het niet helemaal, maar het } \\
\text { klonk niet aardig. El-foula betekende } \\
\text { "tuinboon.” Werd hij soms voor } \\
\text { tuinboon uitgescholden? Dat was weer } \\
\text { iets nieuws. (Laroui 2012a: 123) } \\
\text { Italian: La strega lo guardò con ostilità } \\
\text { e disse, in arabo, facendo il muso: - } \\
\text { Gueddou gued el-foula! Mehdi non } \\
\text { comprese tutto, ma non sembrava } \\
\text { un'esclamazione molto gentile. El-- } \\
\text { foula voleva dire fava. Gli davano della } \\
\text { fava? Era una novità. (Laroui 2015b: } \\
\text { 140-141) }\end{array}$ \\
\hline
\end{tabular}

Examples 7 and 15 mainly stress Mehdi's naivety with a smiling irony. Other times, when Laroui rails against a certain form of linguistic nationalism, irony becomes slightly harsher and can reach absurd reasoning: 


\section{Example 16}

\begin{tabular}{|c|c|c|}
\hline ST & Backtranslation & TT \\
\hline $\begin{array}{l}\text { Quelques instants plus tard } \\
\text { arriva un jeune serveur du } \\
\text { nom de Gustave - c'est ainsi } \\
\text { qu'il se présenta, en saluant } \\
\text { Adam [...]. II parlait anglais } \\
\text { avec un effroyable accent } \\
\text { français. Adam en déduisit } \\
\text { qu'il était probablement } \\
\text { hongrois ou arménien.[...] } \\
\text { Quant au vin, c'est mon ami } \\
\text { le docteur Serghini [...] qui } \\
\text { le choisira: attention, c'est } \\
\text { un connaisseur, il vient de } \\
\text { Paris. Gustave se tourna } \\
\text { vers Adam. II le regarda } \\
\text { d'un air vaguement } \\
\text { hostile. - Z'êtes } \\
\text { français? - Jawohl. — Moi } \\
\text { aussi. J'viens d'Marseille. } \\
\text { (Laroui 2008b: 37) }\end{array}$ & $\begin{array}{l}\text { A few seconds later a } \\
\text { young waiter came } \\
\text { along, his name was } \\
\text { Gustave, so he said } \\
\text { when introducing } \\
\text { himself to Adam [...]. } \\
\text { He spoke English with } \\
\text { a terrible French } \\
\text { accent. Adam deduced } \\
\text { he must be Hungarian } \\
\text { or Armenian. [...] As } \\
\text { for the wine, my } \\
\text { friend doctor Serghini } \\
\text { [...] will choose it: } \\
\text { watch out, he is a } \\
\text { connoisseur, he is } \\
\text { from Paris. Gustave } \\
\text { turned to Adam. He } \\
\text { gave a vaguely hostile } \\
\text { glance at him. - You } \\
\text { French? - Jawohl. - } \\
\text { Me, too. I'm from } \\
\text { Marseille. }\end{array}$ & $\begin{array}{l}\text { Dutch: Even later verscheen er een jonge } \\
\text { ober, Gustave genaamd - zo stelde hij } \\
\text { zich tenminste aan Adam voor [...] Hij } \\
\text { sprak Engels met een verschrikkelijk } \\
\text { Frans accent. Adam eruit af dat hij } \\
\text { waarschijnlijk van Hongaarse of } \\
\text { Armeense origine was. [...] Wat de wijn } \\
\text { betreft, daar gaat mijn vriend doctor } \\
\text { Serghini [...] over: pas maar op, hij is een } \\
\text { kenner, hij komt uit Parijs. Gustave keek } \\
\text { Adam aan. Zijn blik had iets vaags } \\
\text { vijandigs. "Bè-je Fransman?" "Jawohl." } \\
\text { "Ik ook. Kom uit Marseille." (Laroui } \\
\text { 2008a: 35-36) }\end{array}$ \\
\hline
\end{tabular}

The narrator, Adam, thinks that people speaking English with a strong French accent must be Hungarian or Armenian. As for Cordelia, she assumes that, coming from Paris, Adam is French. Gustave is astonished and double-checks with Adam, who confirms... in German. Irony relates here more clearly to its axiological nature and is openly critical. This example also shows that multilingualism sometimes affects the transformation not only from one language to another, but also from one linguistic register to another. When Gustave asks Adam if he is French, adding that he is from Marseille, he shifts to a clearly more informal language level. The apheresis and the apocope of the pronoun in "Z'êtes français?" and "J'viens d'Marseille" are indeed a feature of spoken French. Both are rendered in translation by Dutch forms that are considered informal, i.e. the apocope of the verb in "Bè-je Fransman?" and the omission of the subject pronoun in "Kom uit Marseille."

This passage also shows that whenever the issue of monolingualism or multilingualism comes up in his novels, Laroui's irony does not only target the citizens of mainly monolingual big nations such as France and the United Kingdom, but rather aims at those who show off their plurilingualism and for whom multilingualism is related to an often violent history of colonialism. Thus, in La fin tragique de Philomène Tralala, the narrator, a Moroccan Francophone writer, has an outburst of Homeric rage when asked why she writes in French (Laroui 2003: 82). On the other hand, when she receives a love poem from a French literary critic who uses a word borrowed from Arabic, she shows an extremely narrow-minded linguistic vision: 
Example 17

\begin{tabular}{|c|c|c|}
\hline ST & Backtranslation & TT \\
\hline $\begin{array}{l}\text { «Quoi, « le flot en son } \\
\text { oued ». [...] Et d'abord quoi } \\
\text { « oued ». Moi, je peux dire } \\
\text { oued, j'en ai le droit, je suis } \\
\text { née au bord! [...] Toi, t'as } \\
\text { qu'à dire « gave », « ru », } \\
\text { « torrent »! Ton terroir, mes } \\
\text { déserts. Chacun chez soi! » } \\
\text { (Laroui 2003: 13) }\end{array}$ & $\begin{array}{l}\text { What, the water in his } \\
\text { oued? [...] And first of } \\
\text { all, what "oued"? I can } \\
\text { say oued, I have the } \\
\text { right, I was born on its } \\
\text { shores! [...] You can } \\
\text { say "torrent," "stream," } \\
\text { "creak!" Your territory, } \\
\text { my deserts. To each his } \\
\text { own. }\end{array}$ & $\begin{array}{l}\text { Dutch: Hoezo, het water in zijn wadi? } \\
\text { [...] Ten eerste, hoezo "wadi”? Dat } \\
\text { mag ik alleen zeggen, dat wadi, daar } \\
\text { heb ik recht op, ik ben aan de oever van } \\
\text { een wadi geboren. [...] Jij mag’t } \\
\text { hebben over "laak", "vliet," "beek!" Jij } \\
\text { jouw streekeigen, ik mijn woestijn. } \\
\text { Ieder zijn thuis. (Laroui 2005: 10) }\end{array}$ \\
\hline
\end{tabular}

In example 17 we find a loanword ("oued"), a lexical category that somehow embodies the metonymic representation of multilingualism in a literary text. Expressions such as this truly emphasize the position of the character as an in-between, i.e. of the author leaving his source culture. While of foreign origin, these expressions have been absorbed by the language, if necessary by means of some adaptation of phonetic, orthographic or morphological nature. Their foreign character, however, has not been completely erased, thus showing very concretely that borders between languages can be far from hermetic.

What is even more ironic, though, is the fact that some characters, while plurilingual, cannot recognize the original language in loanwords. Thus Mehdi, who speaks French, does not understand when Moroccans use terms related to the automobile terminology that are actually borrowed from French.

\section{Example 18}

\begin{tabular}{|c|c|c|}
\hline ST & Backtranslation & $\mathbf{T T}$ \\
\hline $\begin{array}{l}\text { Une discussion enfiévrée se } \\
\text { déroulait entre les quatre } \\
\text { hommes, chacun pointant le } \\
\text { doigt vers un élément } \\
\text { différent du moteur et jetant } \\
\text { d'une voix rude des mots } \\
\text { incompréhensibles. - } \\
\text { L'piniou! L'carbiratour! } \\
\text { L'bila coulate! (Laroui } \\
\text { 2010b: } 44 \text { ) }\end{array}$ & $\begin{array}{l}\text { The four men were } \\
\text { having a very animated } \\
\text { discussion, each of } \\
\text { them pointing his finger } \\
\text { to a different part of the } \\
\text { engine and dropping } \\
\text { incomprehensible } \\
\text { words in a rough } \\
\text { voice: - The kear! The } \\
\text { carbarettor! The } \\
\text { connected road } \\
\text { bushings! }\end{array}$ & $\begin{array}{l}\text { Dutch: Er vond een koortsachtige } \\
\text { discussie tussen de vier mannen plaats, } \\
\text { ieder wees met zijn vinger naar een } \\
\text { ander onderdeel van de motor en riep } \\
\text { met ruwe stem allerlei onbegrijpelijke } \\
\text { woorden: "Versnellungsbakke! } \\
\text { Kaboerator! Kroekasse in de soep!"' } \\
\text { (Laroui 2012a: 42) } \\
\text { Italian: Tra i quattro uomini era in } \\
\text { corso una discussione infervorata, } \\
\text { ciascuno di loro puntava il dito verso } \\
\text { un elemento diverso del motore e } \\
\text { buttava li, con voce rude, parole } \\
\text { incomprensibili. - L'ingreneggio! } \\
\text { L'carbirature! L'abbiella abbronzina! } \\
\text { (Laroui 2015: 49-50) }\end{array}$ \\
\hline
\end{tabular}

Both the Dutch and the Italian translator distort the words of the automobile terminology to try and recreate the French sentence. However, we have to emphasize that there is a basic difference in the feeling of these sentences. The lack of a nomenclature (Laroui 2011a: 61) leaves Moroccans two choices: turning to the high linguistic register of literary Arabic or to 
the more common dialectal Arabic, which includes French loanwords that have fully been integrated in the language (after some phonetic adjustment) and are now currently used to describe those mechanical parts. Nevertheless, while the use of these terms raises the level of dialectal Arabic (Laroui 2011b: 83), the deformation in Dutch and Italian lowers the level of the language and stresses an unfamiliarity with those parts. Needless to say, in this particular example this expedient works perfectly well since the men are in no way familiar with an engine.

Other characters are not aware of the loanwords in their own language. In example 19, a policeman refuses to engage in a discussion on the quite major differences between Arabic and French, but in his answer uses himself "kif-kif bourricot," an expression borrowed from Arabic:

\section{Example 19}

\begin{tabular}{|l|l|l|}
\hline ST & Backtranslation & TT \\
\hline $\begin{array}{l}\text { - On appelle ça des houris, } \\
\text { chef. - Houris, putes, c'est } \\
\text { kif-kif bourricot. (Laroui } \\
\text { 2009: 143) }\end{array}$ & $\begin{array}{l}\text { - They are called } \\
\text { houris, boss. - Houris, }\end{array}$ & $\begin{array}{l}\text { Dutch: Die heten “hoeri's," baas. } \\
\text { Hoeri's of hoeren, [...] allemaal één } \\
\text { pot nat! (Laroui 2010a: 134) }\end{array}$ \\
& thing. & $\begin{array}{l}\text { Italian: - Si chiamano uri, capo. - Uri, } \\
\text { zoccole, è lo stesso. (Laroui 2013: 105) }\end{array}$ \\
\hline
\end{tabular}

This example shows clearly the difference between an expression that has become current in French ("kif-kif bourricot") but can hardly be kept in translation. Both the Dutch and the Italian versions render the meaning but adapt it in their languages. The translation of the word "putes" into Dutch creates a nice pun that is not even present in the source language ("hoeri's of hoeren") and that cannot be present in Italian. A possible English translation, on the other hand, would allow to recreate the Dutch artifice for the word "houris." Only in French, though, can the Arabic loanword translate the point the author is making.

As we can observe, some of these migratory expressions, when crossing borders, also change linguistic register. This is why some loanwords are not considered acceptable in the standard target language. This is precisely what a character tries to explain to her son and to Mehdi:

\section{Example 20}

\begin{tabular}{|c|c|c|}
\hline ST & Backtranslation & TT \\
\hline $\begin{array}{l}\text { D'ailleurs, je te prie de ne } \\
\text { pas dire "maboul”, mais } \\
\text { "fou" ou "insensé" ou } \\
\text { "dement", il y a plein de } \\
\text { mots en bon français, pas } \\
\text { besoin de les remplacer par } \\
\text { un mot vulgaire. - } \\
\text { "Maboul”, c'est vulgaire? } \\
\text { Mais papa m'a dit que ça } \\
\text { venait de l'arabe mahboul, } \\
\text { qui est un vrai mot. N'est-- } \\
\text { ce pas, Mehdi? Mehdi, } \\
\text { prudemment, ne répondit }\end{array}$ & $\begin{array}{l}\text { By the way, please } \\
\text { don't use the word } \\
\text { "weirdo," you can say } \\
\text { "mad" or "bizarre" or } \\
\text { "lunatic", there's plenty } \\
\text { of words in good } \\
\text { French, no need to } \\
\text { replace them with } \\
\text { coarse language. - } \\
\text { "Weirdo*" is coarse } \\
\text { language? But Dad told } \\
\text { me that it came from } \\
\text { the Arabic mahboul, }\end{array}$ & $\begin{array}{l}\text { Dutch: Ik vind trouwens niet dat je het } \\
\text { over "die mafkees" mag hebben, zeg } \\
\text { dan liever zoiets als "gek" of } \\
\text { "gestoord" of "krankzinnig", daar } \\
\text { bestaan genoeg woorden voor, daar } \\
\text { hoef je niet per se zo'n plat woord voor } \\
\text { te gebruiken. "Is dat zo'n plat woord, } \\
\text { "mafkees"? Papa zegt dat het zoiets iets } \\
\text { als wat ze in het Arabisch maboul } \\
\text { noemen, en dat is daar een heel } \\
\text { normaal woord. Nietwaar, Mehdi? } \\
\text { Mehdi hield wijselijk zijn mond. [...] } \\
\text { Madame Berger haalde haar schouders }\end{array}$ \\
\hline
\end{tabular}




\begin{tabular}{|c|c|c|}
\hline $\begin{array}{l}\text { rien. [...] Mme Berger } \\
\text { haussa les épaules. - Ton } \\
\text { père, le philologue du } \\
\text { dimanche... Oui, bon, en } \\
\text { arabe, c'est peut-être } \\
\text { correct mais en français, } \\
\text { "maboul”, c'est... Elle } \\
\text { hésita un peu, épiant Mehdi } \\
\text { à la dérobée puis elle se } \\
\text { décida. - C'est du langage } \\
\text { populaire, de l'argot. } \\
\text { (Laroui 2010b: 224) }\end{array}$ & $\begin{array}{l}\text { which is an actual word. } \\
\text { Isn't it, Mehdi? } \\
\text { Cautiously, Mehdi did } \\
\text { not answer. [...] Mrs. } \\
\text { Berger shrugged her } \\
\text { shoulders. - Your dad, } \\
\text { the amateur } \\
\text { philologist... Ok, yes, it } \\
\text { may be correct in } \\
\text { Arabic, but in French, } \\
\text { "weirdo" is... She } \\
\text { hesitated, furtively } \\
\text { looking at Mehdi, then } \\
\text { went for it. - It's very } \\
\text { ordinary, it's slang.] } \\
\text { * Maboul, in French, } \\
\text { originating the } \\
\text { misunderstanding in the } \\
\text { original language. }\end{array}$ & $\begin{array}{l}\text { op. "Je vader altijd met zijn } \\
\text { filologische praatjes" Na ja, misschien } \\
\text { is het zo in het Arabisch, maar in onze } \\
\text { taal is "mafkees" meer... Ze aarzelde, } \\
\text { wierp een snelle blijk naar Mahdi en } \\
\text { zei toen gedecideerd : "Het is volkstaal, } \\
\text { straattaal." (Laroui 2012a: 198) } \\
\text { Italian: Tra l'altro, ti prego di non dire } \\
\text { "strampalato"33 ma "matto" o } \\
\text { "bizzarro" o "folle" ci sono un sacco di } \\
\text { parole in buon francese, non c'è } \\
\text { bisogno di sostituirle con una parola } \\
\text { dozzinale. - "Strampalato" è } \\
\text { dozzinale? Ma papà mi ha detto che } \\
\text { veniva dall'arabo mahboul, che è una } \\
\text { parola vera. Giusto Mehdi? Mehdi, } \\
\text { prudentemente, non rispose nulla. } \\
\text { Guardava il libro aperto. Madame } \\
\text { Berger alzò le spalle. - Tuo padre è un } \\
\text { filologo della domenica... Sì, va bene, } \\
\text { in arabo forse è corretto, ma in francese } \\
\text { è... Esitò un po', spiando di sottecchi } \\
\text { Mehdi, quindi si decise. - È linguaggio } \\
\text { popolare, gergale. (Laroui } 2015: 231 \text { ) } \\
\text { 33 "Maboul", in francese, da cui deriva } \\
\text { lo scambio che segue nel testo. [N.d.T.] }\end{array}$ \\
\hline
\end{tabular}

If the principle that the mother is explaining to her son is undeniably correct, the little Moroccan boy, and the reader with him, cannot help but wonder if it is just an unfortunate coincidence that an Arabic word be considered coarse language in French. All characters here perfectly realize that the situation is awkward, and their unease, more or less openly shown, is clearly part of the humorous and bittersweet nature of this passage.

The term "maboul," which is part of the French language and comes from an Arabic word, is hardly translatable as such in different cultures, where Arabic has not penetrated the language as much as in French. This is why both versions in Dutch and Italian have to find alternatives. In Italian, the term "strampalato" tries to reproduce the French sound because of the following remark: "Weirdo is vulgar? But Dad told me it comes from the Arabic mahboul, which is an actual word." Still, the chosen adjective is lower in register than the following examples of "proper language" made by the mother, thus replicating the highbrow comment she is making and that the kids are finding weird. The Italian translator explains in a footnote the Arabic term.

The same thing happens in Dutch, where the first time the term "maboul" occurs, it is rendered by "mafkees," which means "crazy," i.e. an adjective in an informal register. However, unlike the Italian translation, the Dutch text does not have a footnote indicating the Arabic term. Therefore, in the Dutch version Mehdi's friend does not say that the term is being borrowed from Arabic, but that it is similar to the Arabic term "maboul," further explaining that it belongs to a very low register. The linguistic argument is thus different, but it still pinpoints the reflection about multilingualism and linguistic variations.

Laroui develops this reflection a little further down in his novel. As example 21 shows, the mother seems to forget what she thinks of the word "maboul" (weird), a detail that her 
son obviously picks up and points out to her. She apologizes, but at the same time uses an English expression to do so: nobody's perfect.

\section{Example 21}

\begin{tabular}{|c|c|c|}
\hline ST & Backtranslation & TT \\
\hline $\begin{array}{l}\text { "Il était peut-être vraiment } \\
\text { maboul, ce Van Gogh." } \\
\text { Denis cria: - "Maboul", tu } \\
\text { as dit "maboul", maman! } \\
\text { Elle haussa les épaules. - } \\
\text { Oui, bon, nobody's perfect. } \\
\text { (Laroui 2010b: 227) }\end{array}$ & $\begin{array}{l}\text { Maybe he really was a } \\
\text { weirdo, this Van } \\
\text { Gogh. - "Weirdo," you } \\
\text { said "weirdo," mom! } \\
\text { cried Denis. Mrs. } \\
\text { Berger shrugged her } \\
\text { shoulders. - Well, ok, } \\
\text { nobody's perfect. }\end{array}$ & $\begin{array}{l}\text { Dutch: "Misschien was hij wel echt } \\
\text { maf, die Van Gogh.” Denis riep: } \\
\text { "Maf", je zei "maf", mama!' Ze haalde } \\
\text { haar schouders op. Oké, goed hoor, } \\
\text { nobody's perfect. (Laroui 2012a: 200) } \\
\text { Italian: Forse è davvero strampalato, } \\
\text { questo Van Gogh. - "Strampalato", hai } \\
\text { detto "strampalato", mamma! Madame } \\
\text { Berger alzò le spalle. - Sì, va bene, } \\
\text { nobody's perfect. (Laroui 2015b: 234) }\end{array}$ \\
\hline
\end{tabular}

Laroui's irony interestingly appears to be addressing multiple targets, men and women, adults and children, French and Moroccans, teachers and policemen. Its use seems to be twofold: on the one hand, it depicts a situation the way only an outsider manages to acknowledge it; on the other hand, it sometimes becomes self-mockery and allows a character (Mehdi in Une année chez les Français and each main character in the short stories) to describe the difficulty of finding oneself in a particular situation. Therefore, by means of irony the author gives a critical view on the outside world and also makes an explicit declaration of a complex inner world and a feeling of unease. The presence of multiple languages and cultural references adds to the interest of these passages.

Laroui's works embrace his multilinguistic background as well as his irony and humour. Irony is generally considered by literary critics and scholars his signature style, and while it is true that he chooses to avoid all irony in some of his writings (e.g. in the short story "Être quelqu'un" in the collection Le jour où Malika ne s'est pas mariée, a dramatic account of a Moroccan migrant trying to reach the coasts of Europe), it can generally be regarded as the way he chooses to look at the astonishing facts that happen in life.

It is thus important to remember that not all the irony present in Laroui's works is the result of an intentional act of artifice, but rather the lens through which he perceives the world around him. This may seem less interesting with regard to translation, yet it is not, since as first and last readers (Gentzler 2001; Piglia 2014), translators will have to feel if a pun or wordplay is deliberately "artificial" or simply the author's way to express a thought. If the pun or wordplay cannot be "directly" translated (Delabastita 1996; Henry 2003), knowing their connotation will guide the translator towards a more literal or a freer translation (Zabalbeascoa 2005).

\section{Translation of multilingual humour}

Translators are usually confronted with a source language and culture that they have to transpose in their target language and culture. The difficulty arising from translating a multilinguistic and multicultural author consists precisely in changing this equation. Both the source language and culture thus become wider and more complex, increasing the level of difficulty for the translator, who finds herself/himself in an even more intricate labyrinth. As 
Antoine Berman points out, though, translation can become l'auberge $d u$ lointain, a place where all things foreign can find a home. In order to achieve this, the translator must find "le non-normé de la langue maternelle pour y introduire la langue étrangère et son dire" (Berman 1999: 131).

At the same time, as Katharina Barbe observes, "We cannot get away from the fact that irony as well as translation are types of interpretation and are, therefore, bound to idiosyncrasies of each language user" (Barbe 1995: 168). The wider the references, the more the boundaries set by one language become looser. Thus, a situation that could potentially be more difficult ends up disclosing new possibilities in translation.

In order to clearly distinguish between the various languages in the translation of multilingualism, Corrius et Zabalbeascoa (2011) suggest the term "third language:"

The third language (L3) is neither L1 in the ST nor L2 in the TT; it is any other language(s) found in either text. [...] L3 is used here as a short form for the third language; L3 ${ }^{\mathrm{ST}}$ is short for the L3 of a source text, and L3 ${ }^{\mathrm{TT}}$ for the third language of the target text (translation). (114)

In the corpus we have chosen to examine, L1 is therefore French and the various L2 are mainly Dutch and Italian. The peculiarity in Laroui's works is that they present numerous L3, among which dialectal Arabic, English, Spanish, Latin and sometimes even Dutch. However, the texts where Dutch is to be found as L3 have not (yet) been translated. Hence our corpus does not show any examples of L $3^{\mathrm{ST}}$ corresponding to L2, a very specific case that raises several issues from the standpoint of translation and translation studies (Corrius \& Zabalbeascoa 2011: 119).

Concerning the link between meaning and form of instances of L3 in the source text, we have identified three situations.

- L3 is present as such, without any formal modification. Sometimes these situations simply reflect the context of the enunciation (examples 1, 2, 3, 4, 5, 6 and 12), at other times, L3 is used in an ironic way (examples 14, 16 and 17).

- $\quad$ L3 is actually an instance in which L3 $\left(\sim \mathrm{L} 3^{\mathrm{ST}}\right)$, and sometimes even the source language $(\sim \mathrm{L} 1)$ are distorted. The humour in these passages actually lies in the fact that the characters are not (at all) fluent in the language involved (examples 7 , $8,9,10,11,12$ and 13$)$.

- The source text contains loanwords (examples 17, 19, 20 and 21). In our corpus they are mostly French words of Arabic origin ( $\left.\mathrm{L} 3^{\mathrm{ST}}=\mathrm{L} 1\right)$. The difficulty for translators consists here in the fact that target languages often do not have a loanword coming from the same L3 as the source language.

We are going to further develop these three situations. However, as a general rule we can already say that it is essential for translators to understand how to deal with the function of multilingualism and the way it is organized in the source text. The author can use various strategies (that translators can quite easily imitate), such as intertextual or paratextual addons assuring the comprehension of L3 by his readership. In this regard, it is important to mention that Laroui started publishing himself a glossary of Arabic words and expressions at the end of his French books after 2014. We have noticed a different use of footnotes and glossaries in the two languages in translation we have examined: the Italian translator has always used some footnotes and a final glossary that was agreed upon with the Italian publisher, even before Laroui started doing so himself; the Dutch translator does not use any footnotes or a glossary. 


\subsection{The translation of $\mathrm{L3}$}

Before starting our analysis, we assumed that a different L3 in the source text would be the same in the target texts. We have noticed that most of the times L3 in the source text is indeed the same L3 as in the target texts: $\mathrm{L} 3^{\mathrm{ST}}=\mathrm{L} 3^{\mathrm{TT}}$. This strategy is to be found mainly when Laroui is already explaining the code switching by means of intertextual translation (examples 1 and 2) in the source text itself. It is also to be found when multilingualism implies an axiological element and is therefore more ironic than simply humorous (examples 16, 17, 19, 20 and 21). This strategy is put in place systematically when L3 is a living language such as English, dialectal Arabic, Spanish and Dutch. However, we have noticed that when it comes to Latin in the Dutch translations (see examples 3, 4 and 5), Latin in the source text is rendered by Dutch expressions.

\subsection{The translation of distorted language}

Most of the times, the examples of L3 we have found are existing languages, though at times they may be more or less distant from the standard language. Some characters express themselves by means of a language they are not totally fluent in. In our corpus, this language is mostly French. In Une année chez les Français, the kid-narrator is himself sometimes lost when it comes to the Latin his attendant uses (example 7) and reproduces the Latin sentence ("dulce et decorum") but distorts it. These examples (examples 7, 8, 9, 10, 11, 12 and 13) show that this modus operandi belongs to the traditional comic technique and plays an important role in the humorous tone of the texts. However, it is interesting to observe the function of linguistic distortions in the source text. At times, they are humorous per se, whereas other times they add to comic puns (examples 7, 13 and 19). In some passages, the distorted language concerns an L3 such as English (examples 8 and 9) or Latin (example 12); in other passages, however, it is a simple deformation of French (examples 13, 16 and 18).

Concerning the translation of approximate language in the source text, we have noticed different approaches. They are likely due to the different situations in which the language deformation occurs. The approximate language is sometimes adapted to the target language $\left(\mathrm{L} 3^{\mathrm{ST}} \sim \mathrm{L} 1 \rightarrow \mathrm{L}^{\mathrm{TT}} \sim \mathrm{L} 2\right)$. This is the most frequent choice for his translators, although not systematic (see example 3 in Dutch, example 7 in Italian and example 19 "houris" in Dutch and Italian) whenever there is a pun (examples 12 and 14) or when the distorted language is French (examples 13, 16 and 18). When there is no pun and the distorted language is English, the target text keeps the same approximate language as the source text $\left(\sim \mathrm{L} 3^{\mathrm{ST}} \sim \mathrm{L} 1 \rightarrow\right.$ $\left.\mathrm{L} 3^{\mathrm{TT}} \sim \mathrm{L} 1\right)$.

\subsection{The translation of loanwords}

In three cases ("kif-kif bourricot" in example 19 and "maboul" in examples 20 and 21), multilingualism basically consists in the use of a loanword in the source language. This situation is an extreme case. Strictly speaking, these are not proper instances of multilingualism, since these loanwords are definitely French $\left(\mathrm{L} 33^{\mathrm{ST}}=\mathrm{L} 1\right)$, albeit of obvious foreign origin. There are several Arabic loanwords in French, and Laroui quite naturally uses them. However, the examples of translation of loanwords in our corpus are insufficient to draw conclusions. In fact, sometimes translators keep them while adding an intertextual element (example 20 in Dutch) or a paratextual element (example 20 in Italian). Finally, the loanword is sometimes replaced by a word in the target language (examples 19 and 21). 


\section{Conclusion}

“Je n'ai qu'une langue, ce n'est pas la mienne" (Derrida 1996: 13): I only have one language, and it is not mine. This sentence at the core of Jacques Derrida's Le monolinguisme de l'autre can well be applied to the case of Fouad Laroui. Not only do they both share the definition of Franco-Maghrebi, they also share a multilinguistic background and an experience of transculturality. The situation of diglossia in Arabic-speaking countries determines early contacts with more than one language. Monolingualism thus becomes bilingualism if not plurilingualism. Laroui's biography, from the early studies at Lycée Lyautey in Casablanca to academic experiences in France and England and a life in the Netherlands, has made him a transcultural (Welsch, 1999) author. His transculturality has inevitably led to a multilingualism and eventually to the heterolingualism defined by Grutman (1997) as the use of foreign languages or social, regional, and historical language varieties in literary texts. In Laroui's case, languages and language registers often portray different cultures, and irony becomes a way for him to reconcile all the worlds he has encountered in the one big, varicoloured world he masterfully portrays.

In Laroui, the issue of multilingualism and multiculturalism - which is more and more important in our society in the light of the multiple crises affecting it - is mostly treated with humour and irony. This is a particularly interesting element of his writing, since this approach allows him to present his readership with different perspectives simultaneously while inspiring both laughter and reflection. We believe this is a fundamental feature of the source text that translators have to consider. It also shows the "need for flexible, relativistic concepts and multifaceted, eclectic approaches as a necessary condition for grasping the complex functions of heterolingualism in/and translation" (Meylaerts 2006: 12).

Translators can often rely on intertextual and paratextual processes whenever the author uses the same strategy. In our examples, translators can mostly reproduce L3 in their target texts. However, when the language is distorted, translators treat it differently. If the distortion occurs in French, there are many adaptations and translations by means of a distorted target language. If the language is originally English, however, the outcome is often a nontranslation, which is usually the same strategy adopted when the original language produces a humoristic effect. Finally, when the linguistic distortion implies a pun, it is usually rendered by an adaptation of the target language. As for loanwords, our corpus is insufficient for us to outline precise strategies.

Since multilingual humour and irony are relatively explicit (Vandaele 2002: 150; Selle 2004) and particularly recurring in Laroui, the first difficulty for his translators is not necessarily their recognition or identification. As we could appreciate from our analyses of the Dutch and Italian published translations, source texts such as Laroui's allow translators to widely explore their creativity.

\section{References}

Barbe, K. (1995). Irony in context. New York: John Benjamins.

Berman, A. (1999). La traduction et la lettre ou l'auberge du lointain. Paris: Seuil.

Chiaro, D. (2017). 'Humor and translation', in Attardo, S. (ed.), The Routledge Handbook of Language and Humor, 414-429.

Corrius, M., \& Zabalbeascoa, P. (2011). 'Language variation in source texts and their translations: The case of L3 in film translation' Target. International Journal of Translation Studies 23(1), 113-130.

Delabastita, D. (1996). 'Introduction'. Target 2(2), 127-139. 
Delabastita, D., \& Grutman, R. (2005). 'Introduction. Fictional representations of multilingualism and translation'. Linguistica Antverpiensia, New Series - Themes in Translation Studies 4, 11-34.

Denooz, L. (2011) 'Entre deux mondes : imposture ou créolisation? Fouad Laroui, Une année chez les Français', in Denooz, R. \& Dollet-Thiéblemont, S. (eds.), Le Moi et l'Autre. Études pluridisciplinaires. Questions de communication, Nancy, PUN, 89-98.

Derrida, J. (1996). Le monolinguisme de l'autre ou la prothèse d'origine. Paris: Galilée.

Ferguson, C. A. (1959). 'Diglossia'. Word, 5, 325-340.

Gentzler, E. (2001). Contemporary translation theories (Vol. 21). Clevedon: Multilingual Matters.

Grutman, R. (1997). Des langues qui résonnent. L'hétérolinguisme au XIXe siècle québécois. Montréal: Fides.

Hamon, P. (1996). L'ironie littéraire: essai sur les formes de l'écriture oblique. Paris: Hachette.

Henry, J. (2003). La traduction des jeux de mots. Paris: Presses Sorbonne Nouvelle.

Hutcheon, L. (1998). 'Irony, nostalgia, and the postmodern', in Vervliet, R. (ed), Methods for the Study of Literature as Cultural Memory, Amsterdam: Rodopi, 189-207.

Laroui, F. (1999a). Kijk uit voor parachutisten (F. v. Woerden, Trans.). Amsterdam: Van Oorschot.

Laroui, F. (1999b). Méfiez-vous des parachutistes. Paris: Julliard.

Laroui, F. (2001a). Judith en Jamal (F. v. Woerden, Trans.). Amsterdam: Van Oorschot.

Laroui, F. (2001b). Vreemdeling: aangenaam. Amsterdam: Van Oorschot.

Laroui, F. (2002a). De tanden van de topograaf (F. v. Woerden, Trans.). Amsterdam: Van Oorschot.

Laroui, F. (2002b). Verbannen woorden. Amsterdam: Vassallucci.

Laroui, F. (2003). La fin tragique de Philomène Tralala. Paris: Julliard.

Laroui, F. (2004a). De uitvinding van God (F. v. Woerden, Trans.). Amsterdam: Van Oorschot.

Laroui, F. (2004b). Hollandse woorden. Amsterdam: Vassallucci.

Laroui, F. (2005). Het tragische einde van Philomène Tralala (F. Van Woerden, Trans.). Amsterdam: Van Oorschot.

Laroui, F. (2008a). De rijkste vrouw van Yorkshire (F. v. Woerden, Trans.). Breda: De Geus.

Laroui, F. (2008b). La femme la plus riche du Yorkshire roman. Paris: Julliard.

Laroui, F. (2009). Le jour où Malika ne s'est pas mariée. Paris: Julliard.

Laroui, F. (2010a). De dag dat Malika niet trouwde (F. v. Woerden, Trans.). Breda: De Geus.

Laroui, F. (2010b). Une année chez les Français. Paris: Julliard.

Laroui, F. (2011a). La vieille dame du riad. Paris: Julliard.

Laroui, F. (2011b). Le drame linguistique marocain. Léchelle: Zellige.

Laroui, F. (2012a). De kleine bedrieger: een jaar bij de Fransen (F. v. Woerden, Trans.). Breda: De Geus.

Laroui, F. (2012b). L'étrange affaire du pantalon de Dassoukine. Paris: Julliard.

Laroui, F. (2013). L'esteta radicale (C. Vezzaro, Trans.). Rome: Del Vecchio.

Laroui, F. (2015a). Die alte Dame in Marrakesch (C. Kayser, Trans.). Gifkendorf: MerlinVerlag.

Laroui, F. (2015b). Un anno con i francesi (C. Vezzaro, Trans.): Del Vecchio Editore.

Laroui, F. (2016a). Ce vain combat que tu livres au monde. Paris: Julliard.

Laroui, F. (2016b). The curious case of Dassoukine's trousers (E. Ramadan, Trans.). Dallas, Texas: Deep Vellum Publishing. 
Lievois, K. (2008). 'La traduction de l'allusion ironique dans La fin tragique de Philomène Tralala de Fouad Laroui : Quand l'autre n'est pas celui que l'on croit'. Expressions maghrébines 7(2), 113-128.

Lievois, K. (2014). '« Moi je pas savoir, mon capitaine » ou traduire le français-tirailleur dans les romans francophones africains de la première génération', in F. Naudillon (ed.), Les littératures francophones au miroir du populaire, Calgary: Palabres editions, 181-200.

Lievois, K. (2017). 'La traduction de l'allusion intertextuelle'. MonTI 9, 125-148.

Meylaerts, R. (2006) 'Heterolingualism in/and translation: How legitimate are the other and his/her language? An introduction'. Target. International Journal of Translation Studies 18(1), 1-15.

Piglia, R. (2014). El último lector. Barcelona: Penguin Random House.

Redouane, N., Bénayoun-Szmidt, Y., \& Rey Mimoso-Ruiz, B. (2018). Fouad Laroui. Paris: L'Harmattan.

Rey Mimoso-Ruiz, B. \& Redouane, N. (2018). 'Humanisme et dérision: l'oeuvre de Fouad Laroui', in Redouane, N., Bénayoun-Szmidt, Y., \& Rey Mimoso-Ruiz, B., Fouad Laroui, Paris: L'Harmattan, 31-96.

Schoentjes, P. (2001). Poétique de l'ironie. Paris: Seuil.

Selle, R. (2004). 'Literary style in translation: Humour and irony', in Kittel, H., Frank, P.A. \& Greiner, N. e. a. (eds.), Übersetzung-Translation-Traduction. Ein internationales Handbuch zur Übersetzungsforschung, Berlin: De Gruyter, 875-882.

Vandaele, J. (2002). 'Introduction. (Re-)constructing humour: Meaning and means'. The Translator: Studies in Intercultural Communication 8(2), 149-172.

Vezzaro, C. (2016). 'Translating Fouad Laroui: a journey through languages and cultures', in Sepp, A. \& Humblé, P. (eds.), Bearing Across: Translating Literary Narratives of Migration, Trier: Wissenschaftlicher Verlag, 159-171.

Welsch, W. 'Transculturality - the puzzling form of cultures today'. Accessed on January 7 2019 at http://www2.uni-jena.de/welsch/papers/W_Wlelsch_Transculturality.html.

Zabalbeascoa, P. (2005). 'Humor and translation - an interdiscipline'. Humor 18(2), 185-207. 